\title{
Monoclonal antibody treatment during pregnancy and/or lactation in women with MS or neuromyelitis optica spectrum disorder
}

Andrea Ines Ciplea, Annette Langer-Gould, MD, PhD, Annick de Vries, PhD, Tiny Schaap, BSc, Sandra Thiel, PhD, Marius Ringelstein, MD, Ralf Gold, MD, and Kerstin Hellwig, MD

Neurol Neuroimmunol Neuroinflamm 2020;7:e723. doi:10.1212/NXI.0000000000000723

\section{Abstract}

\section{Objective}

To assess possible adverse effects on breastfed infants of mothers receiving monoclonal antibodies (MAbs) during pregnancy and/or lactation.

\section{Methods}

We identified 23 patients from the German Multiple Sclerosis and Pregnancy Registry (DMSKW) who received MAbs (17 natalizumab and 6 anti-CD20) during lactation. Thirteen were already exposed to natalizumab during the third trimester of pregnancy, and 1 received ocrelizumab during pregnancy. Data were obtained from standardized, telephone-administered questionnaires completed by the mother during pregnancy and at 1, 3, 6, and 12 months postpartum. Natalizumab concentration in mother's milk was analyzed in 3 patients and natalizumab serum concentration in 2 of these patients and their breastfed infants.

\section{Results}

We did not observe a negative impact on infant health and development attributable to breast milk exposure after a median follow-up of 1 year. Infants exposed to natalizumab during the third trimester had a lower birth weight and more hospitalizations in the first year of life. The concentration of natalizumab in breast milk and serum of infants was low; B cells normal in infants breastfed under anti-CD20.

\section{Conclusion}

More data on the effect of Mab exposure during pregnancy are needed. Otherwise, our data suggest that treatment with natalizumab, ocrelizumab, or rituximab during lactation might be safe for breastfed infants.
Correspondence

Dr. Hellwig

k.hellwig@klinikum-bochum.de 


\section{Glossary}

CBC $=$ complete blood count $\mathbf{M A b}=$ monoclonal antibody; NMOSD $=$ neuromyelitis optica spectrum disorder; NTZ = natalizumab; OCR = ocrelizumab; RID = relative infant dose; $\mathbf{R T X}=$ rituximab.

Monoclonal antibodies (MAbs) are considered compatible with lactation by gastroenterologists and rheumatologists, ${ }^{1,2}$ yet breastfeeding under MAb treatment is generally not recommended by neurologists. Two classes of MAbs, natalizumab (NTZ) and CD20-depleting agents, rituximab (RTX) and ocrelizumab (OCR), are highly effective therapy options for women at a high risk of pregnancy-related MS relapses with apparently undetectable or minimal transfer into breast milk in 7 NTZ-exposed and 10 RTX-exposed breast milk samples. ${ }^{3-6}$ Whether these minimally detectable breast milk levels pose any risk to the infants is unknown, leading many experts to be exceedingly cautious. This is potentially problematic as withholding breastfeeding may deprive the mother and child of multiple important health benefits. ${ }^{7}$ Herein, we present a cohort of 23 women with MS or neuromyelitis optica spectrum disorder (NMOSD) from the German Multiple Sclerosis and Pregnancy Registry (DMSKW) who breastfed under MAbs with follow-up of their offspring.

\section{Methods}

The DMSKW is a prospective nationwide cohort study for pregnant women with MS or NMOSD. Data are collected by a standardized telephone-administered questionnaire at regular intervals during pregnancy and postpartum (pp). ${ }^{8}$ Inclusion criteria for these analyses were live birth and breastfeeding while on MAb treatment through September 2019. Breastfeeding under MAb was defined as breastfeeding for at least 1 day after the first pp MAb infusion. If the last $\mathrm{MAb}$ infusion during pregnancy was administered within 100 days of delivery for NTZ and 130 days for OCR ( $<5$ halflives), infants were considered exposed during breastfeeding from the first day of life. The following outcomes were collected: hospitalization with any overnight admission, any infection requiring antibiotic treatment or hospitalization during the first year of life. For the percentages of infants with $\geq 12$ months of follow-up at least hospitalized or treated with antibiotics once, we included in the numerator the event in any infant (irrespective of the length of follow-up) but in the denominator, only infants with $\geq 12$ months of follow-up.

Weight was compared with age- and sex-specific values obtained from the general German pediatric population, excluding preterm births (<completed 37 weeks of gestation [gw]). 9 Developmental delay was defined as any delay reported by the mother during the interview and confirmed by the treating pediatrician. MS relapses were defined using the current $\mathrm{McD}$ onald criteria. ${ }^{10}$ Anemia and thrombocytopenia were classified as follows: "no" if the proportion of hemoglobin/thrombocytes was $>100 \% />99 \%$ of the laboratory reference value, respectively, "mild" between 100 and 91\%/>50\%, "moderate" between 91 and $64 \% />30 \%$, and "severe" if it was $<64 \% /<30 \%$.

NTZ concentrations in serum and breast milk were determined as described previously by a highly sensitive crosslinking assay ${ }^{11,12}$ at Sanquin Diagnostic Services (Amsterdam, the Netherlands).

The relative infant dose (RID) $)^{13}$ was calculated by dividing the absolute infant dose by the maternal dose. For calculation of the absolute infant dose, the respective maximum NTZ concentration in milk and an estimated daily milk intake of $150 \mathrm{~mL} / \mathrm{kg}$ were used.

\section{Standard protocol approvals, registrations, and patient consents}

The DMSKW is approved by the local institutional review board of the Ruhr University Bochum (18-6474-BR). All women voluntarily enrolled and gave informed consent.

\section{Data availability}

No deidentified patient data will be shared. No related studyrelated documents will be shared. Reasonable requests from any qualified investigator for anonymized data will be considered by the corresponding author.

\section{Results}

Of 2,120 pregnancies, we identified 23 women who breastfed under MAbs: 17 under NTZ, 3 RTX, 2 OCR, and 1 received RTX and OCR. The characteristics of the cohort are shown in table 1; the MAb exposure with relevant outcomes are shown in tables 2 and 3 (stratified according to exposure during the third trimester of pregnancy and breastfeeding and to exposure only during breastfeeding). Most women continued NTZ throughout pregnancy and breastfeeding $(n=13,76 \%)$. Only 1 woman received OCR during pregnancy (2nd trimester) following 2 relapses; she was treated with 3 cycles of alemtuzumab before pregnancy. Three of 4 (17\%) women with relapses during pregnancy were treated with alemtuzumab, fingolimod, or NTZ before but not during pregnancy, and 1 woman continued glatiramer acetate during pregnancy. The first NTZ infusion postpartum was administered after a median of 14 days (range 1-124 days) after the date of delivery and the first RTX infusion after a median of 8 days (range 4-26 days). OCR patients started after 20 and 194 days, and the woman breastfeeding under RTX and OCR received her infusions after 55 and 333 days postpartum, respectively. The 4 women with postpartum relapses had either not been treated with MAbs before $(\mathrm{n}=2)$ or had stopped 
Table 1 Clinical characteristics of the mothers

\begin{tabular}{|c|c|}
\hline Characteristics & Values \\
\hline MS, no. (\%) & $21(91)$ \\
\hline NMOSD, no. (\%) & $2(9)$ \\
\hline Age at conception, $y$, mean (SD) & $34.20(5.39)$ \\
\hline Body mass index at conception, mean (SD) & $24.48(4.95)$ \\
\hline \multicolumn{2}{|l|}{ Education } \\
\hline $\begin{array}{l}\text { Completed university } \\
\text { studies, no. (\%) }\end{array}$ & $12(52)$ \\
\hline $\begin{array}{l}\text { Completed vocational } \\
\text { training, no. (\%) }\end{array}$ & $11(48)$ \\
\hline $\begin{array}{l}\text { Disease duration at conception, } \\
\text { y, mean (SD) }\end{array}$ & $9.22(5.01)$ \\
\hline $\begin{array}{l}\text { EDSS score before pregnancy, } \\
\text { median (range) }\end{array}$ & $2.5(0-6.5)$ \\
\hline $\begin{array}{l}\text { No. of DMTs before NTZ/OCR/RTX, } \\
\text { median (range) }\end{array}$ & $1(0-6)$ \\
\hline $\begin{array}{l}\text { Women with } \geq 1 \text { relapse in the } \\
\text { year preceding pregnancy, no. (\%) }\end{array}$ & $10(43)$ \\
\hline $\begin{array}{l}\text { Women with } \geq 1 \text { relapse during } \\
\text { pregnancy, no. (\%) }\end{array}$ & $4(17)$ \\
\hline $\begin{array}{l}\text { Women with relapses in the } \\
\text { first } 6 \text { months postpartum, no. }(\%)^{b}\end{array}$ & $3(17)$ \\
\hline $\begin{array}{l}\text { Women with relapses in the } \\
\text { first } 12 \text { months postpartum, no. (\%) }\end{array}$ & $4(27)$ \\
\hline $\begin{array}{l}\text { Start MAb treatment postpartum, } \\
\text { d, median (range) }\end{array}$ & $19(1-194)$ \\
\hline $\begin{array}{l}\text { Duration of exposed breastfeeding, } \\
\text { mo, median (range) }\end{array}$ & $6.10(0.33-22.9)$ \\
\hline $\begin{array}{l}\text { Follow-up postpartum, mo, } \\
\text { median (range) }\end{array}$ & $12.30(2.13-49.03)$ \\
\hline $\begin{array}{l}\text { Gestational week at entry into } \\
\text { the cohort, median (range) }\end{array}$ & $13.57(4.14-41.43)$ \\
\hline
\end{tabular}

Abbreviations: DMT = disease-modifying therapy; EDSS = Expanded Disability Status Scale; MAb = monoclonal antibody; NMOSD = neuromyelitis optica spectrum disorder; NTZ = natalizumab; OCR = ocrelizumab; RTX = rituximab.

a Data available for 21 (91\%) women.

${ }^{\mathrm{b}}$ Data available for 18 women.

c Data available for 15 women.

NTZ during the 1st trimester $(\mathrm{n}=2)$. All pregnancy and postpartum relapses were treated with IV corticosteroids.

\section{Pregnancy outcomes}

Four singleton infants (17\%) were born preterm. Two exposed to NTZ through pregnancy were delivered at $36 \mathrm{gw}$ (incompetent cervix) and $37 \mathrm{gw}$ (planned cesarean section because of elevated liver enzymes without other signs for HELLP syndrome (hemolysis, elevated liver enzymes, and low platelet count) (table 2). One infant was delivered in $37 \mathrm{gw}$ due to failure to thrive since $32 \mathrm{gw}$ due to placental insufficiency. The mother (fingolimod before pregnancy) had a severe relapse during pregnancy that required treatment with IV corticosteroids and plasma exchange. Another infant was delivered at $30 \mathrm{gw}$ following premature rupture of membranes from incompetent cervix. The mother had received RTX for 4 years with the last dose 3 months before pregnancy with recurrent urinary tract infections and hypogammaglobulinemia $(465 \mathrm{mg}$ / $\mathrm{dL}$ ) before and during pregnancy and received IV immunoglobulins during pregnancy (table 3 ).

\section{Infant outcomes}

Median birth weight in term infants was 3,315 g (range $2,520-3,690 \mathrm{~g}$ ) in girls and 3,260 $\mathrm{g}$ (range 2,660-3,810 g) in boys but lower in newborns exposed to NTZ in the last trimester of pregnancy (table 4). Physical growth was normal at all well-baby visits during exposed breastfeeding for almost all full-term infants. Only 2 male infants fell below the 3rd percentile with 1 body measurement (birth weight or head circumference at well-baby visits at 1 or 3-4 months of age, respectively), but caught up during exposed breastfeeding. One was exposed to NTZ during the 3rd trimester, and the second only during breastfeeding. In our whole cohort, at least 1 antibiotic treatment was given in $30 \%$ of boys and $15 \%$ of girls. In those infants with at least 12 months of follow-up ( $\mathrm{n}=$ 6 and $n=9), 3$ boys (50\%) and 2 girls $(22 \%)$ received at least 1 antibiotic treatment (expected in the general German population, males: $27 \%$ and females: $25 \%) .{ }^{14}$ So far, $3(30 \%)$ boys and $4(31 \%)$ girls in our cohort have been hospitalized at least once within the first year of life (range of follow-up time 2.8-49.0 months). Considering only those with a follow-up of $\geq 12$ months, 3 boys (50\%) and 4 (44\%) girls were hospitalized. This compares with an expected percentage of $18.7 \%$ in males and $14.9 \%$ in females in Germany. ${ }^{15}$ Four hospitalizations occurred immediately after birth for the following reasons: 2 prematurity and in 2 complications after birth including neonatal infection in both. In 2 cases, hospitalization was a precautionary measure: cough in one and suspicion of gastroenteritis without fever and diarrhea without therapy in the second (table 2). All relevant infections of infants exposed during the third trimester of pregnancy entailed hospitalization (table 2). More infants with third-trimester NTZ exposure were hospitalized compared with unexposed children. Table 4 stratifies our cohort into observed vs expected outcomes according to MAb exposure during the third trimester of pregnancy and during breastfeeding only, in comparison to German reference populations. There was 1 child with a major congenital malformation (ventricular septal defect).

Chronic diseases included pediatric asthma and hazelnut allergy $(\mathrm{n}=1$ each). One infant (NTZ throughout pregnancy) suffers from slight generalized muscular hypotonia due to perinatal asphyxia, but at the age of 6 months his medical examination was satisfactory. No infants had developmental delays.

\section{Hematologic abnormalities}

We received results of complete blood counts (CBCs) during breastfeeding in 7 (41\%) (at birth in 12 [71\%]) infants 
Table 2 Clinical characteristics of infants exposed to natalizumab during the third trimester of pregnancy

\begin{tabular}{|c|c|c|c|c|c|}
\hline Infant & $\begin{array}{l}\text { Pregnancy NTZ interval/last } \\
\text { infusion before DOD (no. of } \\
\text { days) }\end{array}$ & $\begin{array}{l}\text { BF NTZ } \\
\text { interval/ } \\
\text { exposed BF } \\
\text { (mo) }\end{array}$ & $\begin{array}{l}\text { Blood count } \\
\text { time point }^{\mathrm{d}, c}\end{array}$ & $\begin{array}{l}\text { Relevant infections } \\
\text { leading to } \\
\text { hospitalization }^{\mathrm{e}}\end{array}$ & $\begin{array}{l}\text { Hospitalizations other than } \\
\text { infectione/age at occurrence of all } \\
\text { hospitalizations (mo) }\end{array}$ \\
\hline $\operatorname{lm} 1$ & $8-9 / 89$ & $4 w / 6.5$ & NA & Neonatal infection $^{\mathrm{h}}$ & At birth \\
\hline $\operatorname{Im} 2$ & $6 w / 2$ & $6 w / 6.4$ & NA & No & Preterm/at birth \\
\hline If3 & $8 w / 29$ & $6 \mathrm{w} / 2.8$ & $\begin{array}{l}\text { Mild anemia/birth } \\
\text { Normal/+26 }\end{array}$ & No & Preterm/at birth \\
\hline If4 & $6 w / 6$ & $5 \mathrm{w} / 7.2$ & $\begin{array}{l}\text { Normal/birth } \\
\text { Mild anemia/-37 } \\
\text { Normal/-10 } \\
\text { Normal/+6 }\end{array}$ & Cough $^{\mathrm{h}}$ & 1.6 \\
\hline $\operatorname{lm} 5^{f}$ & $7-8 w / 53$ & $7 w / 6.1$ & $\begin{array}{l}\text { Normal/birth } \\
\text { Mild } \\
\text { thrombocytopenia/ } \\
-14 \\
\text { Mild anemia/+87 }\end{array}$ & $\begin{array}{l}\text { Neonatal infection }{ }^{\mathrm{h}} / \\
\text { pyelonephritis }^{\mathrm{h}}\end{array}$ & At birth/3.4 \\
\hline If6 & 6 w/91 & $6 w / 12.6$ & $\begin{array}{l}\text { Normal/birth } \\
\text { Moderate anemia/ } \\
+107\end{array}$ & Gastroenteritis & 3.9 \\
\hline If $7^{g}$ & $6-7 w / 42$ & $7-8 w / 8.1$ & NA & No & No \\
\hline If8 & $6 w / 62$ & $4 w / 6.2$ & NA & No & No \\
\hline If9 & 5 w/19 & $4 w / 2.1$ & NA & No & No \\
\hline Im10 & $6 w / 46$ & $6 \mathrm{w} / 8.7$ & $\begin{array}{l}\text { Normal/birth } \\
\text { Normal/+2 } \\
\text { Normal/+55 }\end{array}$ & No & No \\
\hline If11 & $7 w / 54$ & $5 w / 2.4$ & NA & No & No \\
\hline Im12 & $4 w / 13$ & $8 w / 5.7$ & NA & No & No \\
\hline If13 & $4 w / 16$ & $4 w / 11.2$ & NA & No & No \\
\hline \multicolumn{6}{|c|}{$\begin{array}{l}\text { Abbreviations: BF = breastfeeding; DOD = date of delivery; If = female; Im = male; NA= not available; NTZ= natalizumab; OCR = ocrelizumab; RTX= rituximab. } \\
\text { a From the first day of life. } \\
\text { b Hemoglobin and thrombocytes. } \\
{ }^{c} \text { During exposed breastfeeding. } \\
\text { d Birth or number of days before }(-) \text { or after (+) the 1st infusion postpartum. } \\
\text { e During exposed breastfeeding. } \\
\text { f NTZ3 in the figure. } \\
\text { g NTZ2 in the figure. } \\
\text { h Antibiotic use. }\end{array}$} \\
\hline
\end{tabular}

breastfed under NTZ, 2 of whom were exposed only through breast milk (tables 2 and 3). Both of these infants had normal CBCs. In contrast, only 1 (20\%) of the infants exposed to NTZ throughout pregnancy and through breast milk had continuously normal CBCs, 2 developed mild or moderate hematologic anomalies during breastfeeding, and in total, 5 (50\%) had a mild or moderate anemia and/or mild thrombocytopenia at birth.

Five (83\%) infants exposed to B cell-depleting MAbs during breastfeeding had normal B cells (above the lower limit of normal $600 / \mu \mathrm{L}$ ). In 2 infants (OCR in the 2 nd trimester and RTX 16 months before the date of delivery) the B-cell count was decreased at birth (CD19: 339/ $\mu \mathrm{L}$ and $218 / \mu \mathrm{L}$, respectively) but normalized during exposed breastfeeding at 79 and 93 days postpartum, respectively.

\section{Maternal, infant, and breast milk NTZ levels}

Three mothers provided milk samples at different time points during NTZ-exposed breastfeeding; 2 also provided maternal and infant blood samples to analyze NTZ concentrations in both mothers and babies (figure). Although trace amounts of NTZ were detectable in breast milk $(<1 \%$ of maternal serum values; maximum RID: $0.5 \%$ ), the MAb was not detectable in the infants' sera after pp infusion.

\section{Discussion}

In our small prospective cohort of women with MS and NMOSD breastfeeding under MAbs, we found no signal of harmful clinical or biological effects attributable to breast milk exposure. The infants showed normal growth and no negative 
Table 3 Clinical characteristics of infants unexposed to a monoclonal antibody during the third trimester of pregnancy

\begin{tabular}{|c|c|c|c|c|c|c|}
\hline Infant & $\begin{array}{l}\text { Pregnancy exposure/last } \\
\text { dose before or after LMP }\end{array}$ & BF exposure/interval & $\begin{array}{l}\text { Exposed } \\
\mathrm{BF}^{\mathrm{a}}(\mathrm{mo})\end{array}$ & $\begin{array}{l}\text { Blood count } \\
\text { time point }^{\mathrm{d}, c}\end{array}$ & $\begin{array}{l}\text { Relevant } \\
\text { infections }\end{array}$ & $\begin{array}{l}\text { Hospitalizationsc/age } \\
\text { at occurrence }(\mathrm{mo})\end{array}$ \\
\hline If14 & FTY/-40 & NTZ/6 w & 9.2 & $\begin{array}{l}\text { Normal/birth } \\
\text { Normal/+42 }\end{array}$ & RSV & (preterm) RSV/2.7 \\
\hline If15 & NTZ/+15 & NTZ/4 w & 5.6 & $\begin{array}{l}\text { Normal/ }+3 \\
\text { Normal/ }+89\end{array}$ & No & No \\
\hline $\operatorname{lm} 16^{f}$ & NTZ/+4 & NTZ/6 w & 7.2 & NA & No & No \\
\hline If17 & NTZ/+15 & NTZ/4 w & 0.6 & NA & No & No \\
\hline $\operatorname{Im} 18^{i}$ & OCR/+ 131 & OCR 300 mgg & 2.7 & $\begin{array}{l}\text { Reduced/birth } \\
\text { Normal/+59 }\end{array}$ & No & No \\
\hline $\operatorname{Im} 19$ & $\mathrm{DMF} /+28$ & OCR $600 \mathrm{mg}^{\mathrm{g}}$ & 2.1 & Normal/+39 & No & No \\
\hline $\operatorname{Im} 20$ & GA/continuous & $\begin{array}{l}\text { RTX } 250 \mathrm{mg}+\text { OCR } 300 \\
\text { mg/once + } 6 \text { months }\end{array}$ & 22.9 & $\begin{array}{l}\text { Normal//+45 } \\
\text { Normal/+213 }\end{array}$ & $\begin{array}{l}\text { Conjunctivitis } \\
\text { otitis media }^{\mathrm{h}}\end{array}$ & No \\
\hline $\operatorname{Im} 21$ & RTX/-94 & RTX $500 \mathrm{mg}^{\mathrm{g}}$ & 1.6 & Normal/+63 & No & (preterm) \\
\hline If 22 & RTXI-206 & RTX $1000 \mathrm{mg}^{\mathrm{g}}$ & 1.8 & $\begin{array}{l}\text { Reduced/birth } \\
\text { Normal/+85 }\end{array}$ & Omphalitish $^{h}$ & No \\
\hline If 23 & RTX/-283 & RTX $1000 \mathrm{mg}^{\mathrm{g}}$ & 0.3 & NA & No & No \\
\hline
\end{tabular}

Abbreviations: $\mathrm{BF}=$ breastfeeding; $\mathrm{DMF}=$ dimethyl fumarate; $\mathrm{FTY}=$ fingolimod; $\mathrm{GA}=$ glatiramer acetate; $\mathrm{If}=$ female; $\mathrm{Im}=$ male; $\mathrm{LMP}=$ last menstrual period; $\mathrm{NA}=$ not available; $\mathrm{NTZ}$ = natalizumab; OCR = ocrelizumab; RSV = human respiratory syncytial virus; $\mathrm{RTX}$ = rituximab.

${ }^{a}$ From the day of the first monoclonal antibody infusion postpartum.

${ }^{b} B$ cells if RTX or OCR exposed/hemoglobin and thrombocytes if NTZ exposed.

'During exposed breastfeeding.

${ }^{\mathrm{d}}$ Birth or number of days after (+) the 1st infusion postpartum.

e Requiring antibiotic treatment or hospitalization.

${ }^{\mathrm{f}} \mathrm{NTZ1} 1$ in the figure.

g One administration.

${ }^{\mathrm{h}}$ Antibiotic use.

' OCR in the 2nd trimester.

effect on development. We also observed that infants who were exposed to NTZ during the third trimester of pregnancy had a lower birth weight (both sexes) and were hospitalized more often during the first year of life (both sexes).

The number of infants with at least 1 antibiotic treatment within the first year of life in the total cohort was consistent with expected national rates, ${ }^{14}$ only noticeably elevated in boys with $\geq 12$ months of follow-up. Percentages of infants hospitalized at least once in the total cohort were higher than expected due to the high numbers in third-trimester NTZ-exposed children. As the sample size for the different groups was small and the outcomes rare, it is unclear whether this is a chance finding or if it is related to the treatment during pregnancy, especially because distribution of percentages differed between sex and follow-up period.

We did find an overall lower than expected median birth weight (around $270 \mathrm{~g}$ in boys and $75 \mathrm{~g}$ in girls), albeit not very low, in comparison to the general German population. ${ }^{9}$ This effect was mainly driven by infants exposed to NTZ during the third trimester of pregnancy, which is in line with previous findings after 3rd-trimester NTZ exposure. ${ }^{16}$

We also found a slightly higher than expected number of preterm births (observed: 17\%, expected: $10 \%)^{17,18}$ in the whole cohort, perhaps reflecting the underlying more active MS or drug exposure. Hematologic abnormalities, particularly in those with continuous in utero exposure to NTZ, are well documented and therefore not unexpected. ${ }^{16,19}$ It is very reassuring that these laboratory abnormalities resolved, and the infants grew and developed normally despite continued low-level MAb exposure through breast milk.

We detected very low levels of NTZ in breast milk similar to previous reports. ${ }^{3,4,20}$ A tool to assess the safety of a certain drug exposure via breast milk is the RID. ${ }^{13}$ It is calculated by dividing the absolute infant dose (concentration in breast milk multiplied by daily milk intake $[150 \mathrm{~mL} / \mathrm{kg}])$ by the maternal dose. Drugs with RIDs $<10 \%$ are considered probably safe for a healthy child. ${ }^{21}$ When calculated with the respective maximum concentration in breast milk, maximum RID in our analyses was $0.5 \%$, i.e., far below the theoretically accepted cutoff of $10 \%$. We did not detect accumulation of NTZ in breast milk after up to 4 infusions in contrast to others who found a steady accumulation of NTZ after the 2nd infusion ( $\mathrm{n}$ $=1$ ) and higher levels of NTZ after each additional infusion up to the $2 \mathrm{nd}(\mathrm{n}=2)$ or up to the 4 th administration $(\mathrm{n}=1)$. These dissimilarities are likely due to well-described interindividual variability in natalizumab levels, ${ }^{4,22}$ particularly because both studies are limited by very small sample sizes. 
Table 4 Numbers of observed adverse outcomes in the cohort vs expected

\begin{tabular}{|c|c|c|c|c|c|}
\hline \multirow[b]{3}{*}{ Outcome } & \multirow[b]{3}{*}{ Expected } & \multicolumn{4}{|l|}{ Observed } \\
\hline & & \multirow{2}{*}{$\begin{array}{l}\text { 3rd trimester NTZ } \\
\text { (all infants) } \\
n=13 ; \\
\text { Boys } n=5 \\
\text { Girls } n=8\end{array}$} & \multirow{2}{*}{$\begin{array}{l}\text { 3rd trimester NTZ } \\
\text { ( } \geq 12 \text { months FU) } \\
n=8 \\
\text { Boys } n=3 \\
\text { Girls } n=5\end{array}$} & \multirow{2}{*}{$\begin{array}{l}\text { No 3rd trimester MAb (all } \\
\text { infants) } \\
n=10 ; \\
\text { Boys } n=5 \\
\text { Girls } n=5\end{array}$} & \multirow{2}{*}{$\begin{array}{l}\text { No 3rd trimester } \\
\text { MAb } \\
\text { ( } \geq 12 \text { months FU) } \\
n=7 ; \\
\text { Boys } n=3 \\
\text { Girls } n=4\end{array}$} \\
\hline & & & & & \\
\hline Prematurity & $10 \%^{17,18}$ & $\begin{array}{l}15 \% \text { Cl } 1.92-45.44 \\
(n=2)\end{array}$ & - & $\begin{array}{l}20 \% \text { Cl } 2.52-55.61 \\
(n=2)\end{array}$ & - \\
\hline $\begin{array}{l}\text { Median birth weight, } \\
\text { boys }\end{array}$ & $3,530 \mathrm{~g}^{9}$ & $3,168 \mathrm{~g}$ & - & $3,530 \mathrm{~g}$ & - \\
\hline Median birth weight, girls & $3,390 \mathrm{~g}^{9}$ & $3,315 \mathrm{~g}$ & - & $3,620 \mathrm{~g}$ & - \\
\hline $\begin{array}{l}\geq 1 \text { antibiotic treatment, } \\
\text { boys }\end{array}$ & $27 \%^{14}$ & $\begin{array}{l}40 \% \text { Cl } 5.27-85.34 \\
(n=2)\end{array}$ & $\begin{array}{l}66.7 \% \text { Cl } 9.43-99.16 \\
(n=2)\end{array}$ & $\begin{array}{l}20 \% \text { Cl } 0.51-71.64 \\
(n=1)\end{array}$ & $\begin{array}{l}33.3 \% \text { Cl } 0.84-90.57 \\
(n=1)\end{array}$ \\
\hline $\begin{array}{l}\geq 1 \text { antibiotic treatment, } \\
\text { girls }\end{array}$ & $25 \%^{14}$ & $\begin{array}{l}12.5 \% \text { Cl } 0.32-52.65 \\
(n=1)\end{array}$ & $\begin{array}{l}20 \% \text { Cl } 0.51-71.64 \\
(n=1)\end{array}$ & $\begin{array}{l}20 \% \text { Cl } 0.51-71.64 \\
(n=1)\end{array}$ & $\begin{array}{l}25 \% \text { Cl } 0.63-80.59 \\
(n=1)\end{array}$ \\
\hline$\geq 1$ hospitalization, boys & $18.7 \%^{15}$ & $\begin{array}{l}60 \% \text { Cl 14.66-94.73 } \\
(n=3)\end{array}$ & $\begin{array}{l}100 \% \text { Cl } 29.24-100 \\
(n=3)\end{array}$ & $\begin{array}{l}0 \% \mathrm{Cl} 0-52.18 \\
(\mathrm{n}=0)\end{array}$ & $\begin{array}{l}0 \% \mathrm{Cl} 0-70.76 \\
(\mathrm{n}=0)\end{array}$ \\
\hline$\geq 1$ hospitalization, girls & $14.9 \%^{15}$ & $\begin{array}{l}37.5 \% \mathrm{Cl} 8.52-75.51 \\
(\mathrm{n}=3)\end{array}$ & $\begin{array}{l}60 \% \text { Cl 14.66-94.73 } \\
(\mathrm{n}=3)\end{array}$ & $\begin{array}{l}20 \% \text { Cl } 0.51-71.64 \\
(n=1)\end{array}$ & $\begin{array}{l}25 \% \text { Cl } 0.63-80.59 \\
(n=1)\end{array}$ \\
\hline Developmental delay & $5-6 \%^{28}$ & $0 \% \mathrm{Cl} 0-24.70$ & $0 \% \mathrm{Cl} 0-36.94$ & $0 \% \mathrm{Cl} 0-30.85$ & $0 \% \mathrm{Cl} 0-40.96$ \\
\hline
\end{tabular}

Abbreviations: $\mathrm{FU}=$ follow-up, $\mathrm{MAb}=$ monoclonal antibody, $\mathrm{NTZ}=$ natalizumab.

Even with an increasing amount of the MAb in breast milk, the possibility of systemic absorption in the infant via neonatal Fc receptor seems not to be relevant in humans, ${ }^{23}$ but larger case series are needed to elucidate exact pharmacokinetics.

The decreased B-cell count at birth in the infant whose mother received the last RTX infusion 16 months before the date of delivery cannot be caused by the drug. According to the half-life of RTX of approximately 30 days, the infant could not have been exposed to the drug in utero. An error in analysis is more likely, especially as the B-cell count normalized without any intervention and no chronic disease related to B-cell deficiency was reported.

The low levels of transfer into breast milk are not surprising, as MAbs are large molecules and transfer is limited by molecular weight. ${ }^{13}$ Minimal transfer into breast milk is known for $\mathrm{RTX}^{5,6}$ and unknown but likely for OCR. In published cases of breastfeeding under $\operatorname{RTX}^{5,6}(\mathrm{n}=5)$ and $\mathrm{OCR}^{24}(\mathrm{n}=$ $1)$, no serious adverse effects were reported.

Some have argued that even isolated breast milk exposure to MAbs could have systemic effects in the infant following transluminal absorption via the neonatal Fc receptor, FcRn. Thus, women who need these treatments are often counseled not to breastfeed. This is a theoretically weak argument, as oral absorption of IgG is exceedingly low in human neonates ${ }^{23}$ and the breast milk concentrations of MAbs are already exceedingly low. There is only 1 prior published report of detectable infant serum Mab levels resulting solely from breast milk exposure (infliximab, $\sim 2 \%$ of maternal serum concentration). ${ }^{25}$ In most infants, levels were undetectable. $^{25,26}$ Another report of detectable infant serum levels following infliximab or adalimumab exposure was more likely attributable to late pregnancy exposures than breast milk. ${ }^{27}$ We found that NTZ serum concentrations were undetectable in 2 infants during exposed breastfeeding. In 1 infant, a very low level of NTZ was detected immediately after birth following exposure throughout pregnancy, which resolved despite continued breast milk exposure. Although the number of analyzed samples is very small, our findings seem to further refute the theory of a substantial transfer of MAbs from breast milk via FcRn, which is in line with recommendations of other societies (rheumatology and gastroenterology) who already consider breastfeeding under MAbs to be safe for the infant. ${ }^{1,2}$ Although more studies with larger cohorts and longer follow-ups are needed to evaluate the safety of the individual MAbs, safety will likely be comparable between them and transferable to neurology.

The overlap of MAb exposure during pregnancy and lactation in many infants of our cohort precludes definite conclusions about the safety of exposure through breast milk alone. In combination with the small sample size, this is a limitation of our study. Exposure to MAbs, especially during late pregnancy, could partly confound our results. It can be associated with hematologic abnormalities, ${ }^{16}$ and the infection risk for these neonates is largely unknown. Therefore, more 
Figure Natalizumab concentration in breast milk and blood samples of mothers and their breastfed infants

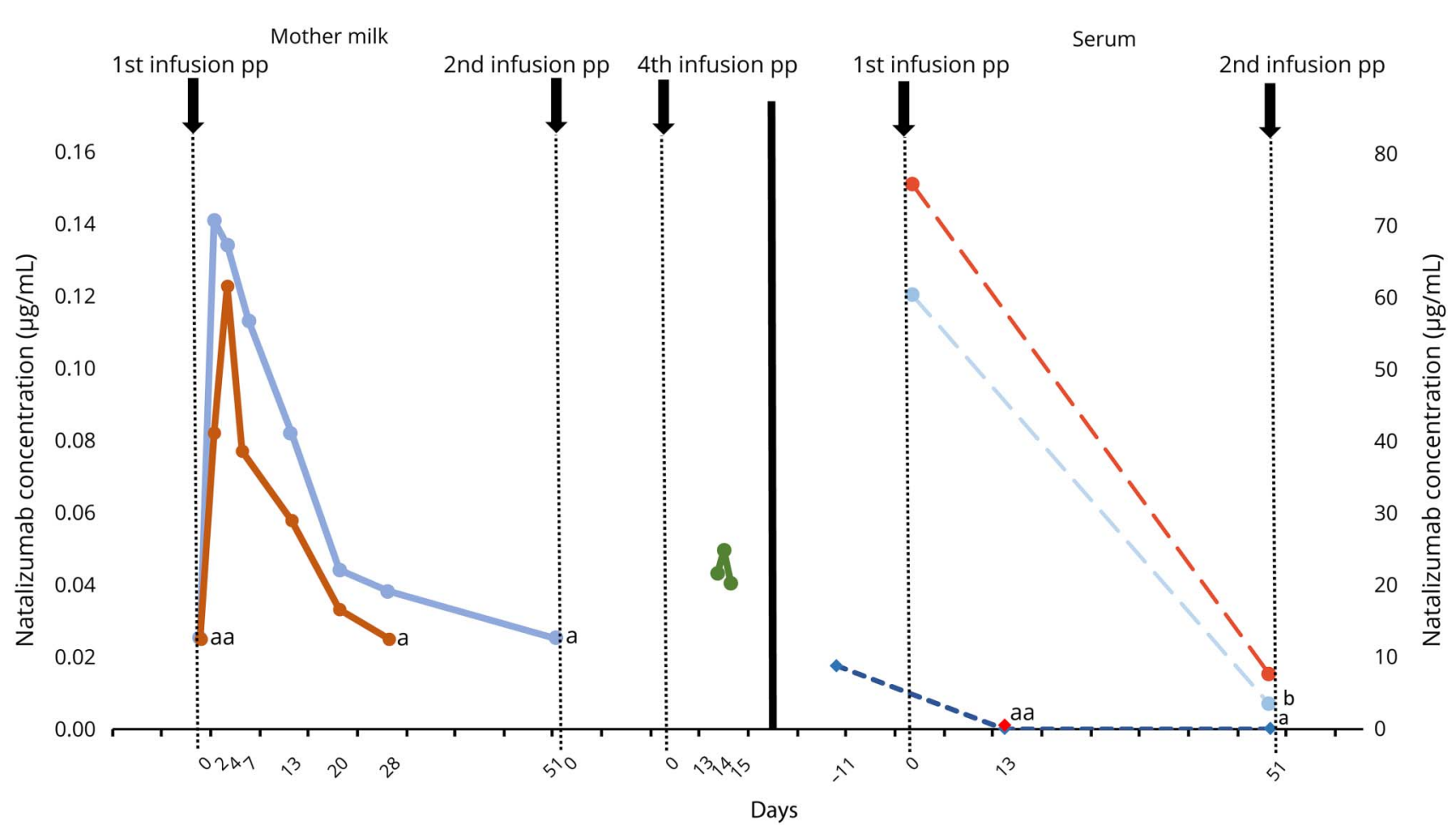

Left: natalizumab concentrations (in micrograms per milliliter) in the breast milk of mothers 2 and 3 on several days after the first infusion postpartum and of mother 1 on several days after the fourth infusion postpartum. Right: natalizumab concentration (in micrograms per milliliter) in sera of mothers 2 and 3 and babies 2 and 3. Maternal serum concentrations were measured at 2 time points after the first infusion postpartum; the serum level of baby 2 was measured before and at 2 points after the first infusion postpartum; for baby 3 , it was available only at 1 time point after the first infusion. ${ }^{a}$ Below the detection limit; bSample stability issues.

information on MAb exposure, especially NTZ, during the 3rd trimester of pregnancy and subsequent follow-up of the infants is necessary. To disentangle the effect of late pregnancy exposure, larger cohorts are needed, with infants exclusively being exposed to MAbs during lactation.

Taken together with other studies, our results underscore the exceedingly low probability of harmful effects of MAbs solely through breast milk. ${ }^{13}$ Women with MS can be advised that although available data are few, these small data sets do not appear to show meaningful adverse effects for infants exposed to breast milk after MAb treatment of the mother. Infants exposed to MAbs during pregnancy should continue to be monitored carefully, and future studies with larger sample sizes should consider the duration of exposed breastfeeding and infants' age at the time of exposure.

\section{Acknowledgment}

The authors thank all the participants of the DMSKW and the referring neurologists and MS nurses.

\section{Study funding}

The German Multiple Sclerosis and Pregnancy Registry (DMSKW) is partly supported by the Innovation Fund of the Federal Joint Committee, Bayer Healthcare Pharmaceuticals, Biogen, Teva Pharma, Novartis, and Merck. The funding organizations had no role in design and conduct of the registry; collection, management, analysis, and interpretation of the data; preparation, review, or approval of the manuscript; and decision to submit the manuscript for publication.

\section{Disclosure}

Andrea I. Ciplea has received speaker honoraria from Bayer Healthcare and travel grants from Sanofi Genzyme, Teva, and Novartis. A. Langer-Gould, A. de Vries, and T. Schaap report no disclosures. S. Thiel has received speaker honoraria from Bayer Healthcare. M. Ringelstein has received speaker honoraria from Novartis, Bayer Vital GmbH, Roche, and Ipsen and travel reimbursement from Bayer Schering, Biogen Idec, Merz, Genzyme, Teva, Grifols, Roche, and Merck, none related to this study. R. Gold has received payments for consultancy from Biogen and Teva and speaker honoraria and research grants from Biogen Idec Germany, Teva, Sanofi Aventis, Novartis, Bayer Healthcare, and Merck Serono. K. Hellwig has received travel grants from Biogen, Novartis, and Merck and received speaker and research honoraria from Biogen Idec Germany, Teva, Sanofi Genzyme, Novartis, Bayer Healthcare, Merck Serono, and Roche. Go to Neurology.org/NN for full disclosures.

\section{Publication history}

Received by Neurology: Neuroimmunology \& Neuroinflammation January 24, 2020. Accepted in final form March 19, 2020. 
Appendix Authors

\begin{tabular}{lll}
\hline Name & Location & Contribution \\
\hline $\begin{array}{l}\text { Andrea Ines } \\
\text { Ciplea }\end{array}$ & St. Josef Hospital, Ruhr & Design of the study, \\
& $\begin{array}{l}\text { University Bochum, } \\
\text { Germany; Heinrich Heine } \\
\text { University Dusseldorf, } \\
\text { Germany }\end{array}$ & $\begin{array}{l}\text { acquisition of data, } \\
\text { interpretation of the data, } \\
\text { drafting the manuscript, } \\
\text { and revision of the } \\
\text { manuscript for intellectual } \\
\text { content }\end{array}$ \\
& &
\end{tabular}

\begin{tabular}{|c|c|c|}
\hline $\begin{array}{l}\text { Annette } \\
\text { Langer- } \\
\text { Gould, MD, } \\
\text { PhD }\end{array}$ & $\begin{array}{l}\text { Southern California } \\
\text { Permanente Medical } \\
\text { Group/Kaiser Permanente, } \\
\text { Los Angeles; Medical } \\
\text { Center, Los Angeles }\end{array}$ & $\begin{array}{l}\text { Interpretation of the data } \\
\text { and revision of the } \\
\text { manuscript for intellectual } \\
\text { content }\end{array}$ \\
\hline $\begin{array}{l}\text { Annick de } \\
\text { Vries, PhD }\end{array}$ & $\begin{array}{l}\text { Sanquin Diagnostic } \\
\text { Services, Sanquin, } \\
\text { Amsterdam, the } \\
\text { Netherlands }\end{array}$ & $\begin{array}{l}\text { Design of the study, } \\
\text { analysis of samples, and } \\
\text { revision of the manuscript } \\
\text { for intellectual content }\end{array}$ \\
\hline $\begin{array}{l}\text { Tiny Schaap, } \\
\text { BSc }\end{array}$ & $\begin{array}{l}\text { Sanquin Diagnostic } \\
\text { Services, Sanquin, } \\
\text { Amsterdam, the } \\
\text { Netherlands }\end{array}$ & $\begin{array}{l}\text { Design of the study, } \\
\text { analysis of samples, and } \\
\text { revision of the manuscript } \\
\text { for intellectual content }\end{array}$ \\
\hline $\begin{array}{l}\text { Sandra } \\
\text { Thiel, PhD }\end{array}$ & $\begin{array}{l}\text { St. Josef Hospital, Ruhr } \\
\text { University Bochum, } \\
\text { Germany }\end{array}$ & $\begin{array}{l}\text { Revision of the manuscript } \\
\text { for intellectual content }\end{array}$ \\
\hline
\end{tabular}

\begin{tabular}{|c|c|c|}
\hline $\begin{array}{l}\text { Marius } \\
\text { Ringelstein, } \\
\text { MD }\end{array}$ & $\begin{array}{l}\text { Department of Neurology, } \\
\text { Medical Faculty, Heinrich } \\
\text { Heine University, } \\
\text { Dusseldorf, Germany; } \\
\text { Department of Neurology, } \\
\text { Center for Neurology and } \\
\text { Neuropsychiatry, LVR- } \\
\text { Klinikum, Heinrich Heine } \\
\text { University Düsseldorf, } \\
\text { Germany }\end{array}$ & $\begin{array}{l}\text { Acquisition of data and } \\
\text { revision of the manuscript } \\
\text { for intellectual content }\end{array}$ \\
\hline
\end{tabular}

\begin{tabular}{lll}
\hline Ralf Gold, & St. Josef Hospital, Ruhr & $\begin{array}{l}\text { Revision of the manuscript } \\
\text { for intellectual content }\end{array}$ \\
MD & $\begin{array}{l}\text { Giversity Bochum, } \\
\text { Germany }\end{array}$ &
\end{tabular}

\begin{tabular}{lll}
\hline Kerstin & St. Josef Hospital, Ruhr & Design of the study, \\
Hellwig, MD & $\begin{array}{l}\text { University Bochum, } \\
\text { Germany }\end{array}$ & $\begin{array}{l}\text { acquisition of data, } \\
\text { interpretation of the data, } \\
\text { and revision of the } \\
\text { manuscript for intellectual } \\
\text { content }\end{array}$ \\
& &
\end{tabular}

\section{References}

1. Mahadevan U, Robinson C, Bernasko N, et al. Inflammatory bowel disease in pregnancy clinical care pathway: a report from the American Gastroenterological Association IBD Parenthood Project Working Group. Gastroenterology 2019;156: 1508-1524.

2. Puchner A, Grochenig HP, Sautner J, et al. Immunosuppressives and biologics during pregnancy and lactation: a consensus report issued by the Austrian Societies of Gastroenterology and Hepatology and Rheumatology and Rehabilitation. Wiener klinische Wochenschrift 2019;131:29-44.

3. Baker TE, Cooper SD, Kessler L, Hale TW. Transfer of natalizumab into breast milk in a mother with multiple sclerosis. J Hum Lact 2015;31:233-236.

4. Proschmann U, Thomas K, Thiel S, Hellwig K, Ziemssen T. Natalizumab during pregnancy and lactation. Mult Scler 2018;24:1627-1634.
5. Krysko KM, LaHue SC, Anderson A, et al. Minimal breast milk transfer of rituximab, a monoclonal antibody used in neurological conditions. Neurol Neuroimmunol Neuroinflamm 2020;7:e637. 10.1212/NXI.0000000000000637.

6. Bragnes Y, Boshuizen R, de Vries A, Lexberg A, Ostensen M. Low level of Rituximab in human breast milk in a patient treated during lactation. Rheumatology (Oxford) 2017;56:1047-1048.

7. Victora CG, Bahl R, Barros AJ, et al. Breastfeeding in the 21st century: epidemiology, mechanisms, and lifelong effect. Lancet (London) 2016;387:475-490.

8. Hellwig K, Haghikia A, Gold R. Pregnancy and natalizumab: results of an observational study in 35 accidental pregnancies during natalizumab treatment. Mult Scler 2011;17:958-963.

9. Neuhauser H, Schienkiewitz A, Schaffrath Rosario A, Dortschy R, BM K. Referenzperzentile für anthropometrische Maßzahlen und Blutdruck aus der Studie zur Gesundheit von Kindern und Jugendlichen in Deutschland (KiGGS). Vol. 2. 2013 Available at: erweiterte Auflage rki.de/DE/Content/Gesundheitsmonitoring/ Gesundheitsberichterstattung/GBEDownloadsB/KiGGS_Referenzperzentile.html. Accessed January 13, 2020.

10. McDonald WI, Compston A, Edan G, et al. Recommended diagnostic criteria for multiple sclerosis: guidelines from the International Panel on the diagnosis of multiple sclerosis. Ann Neurol 2001;50:121-127.

11. Rispens T, Leeuwen A, Vennegoor A, et al. Measurement of serum levels of natalizumab, an immunoglobulin G4 therapeutic monoclonal antibody. Anal Biochem 2011;411:271-276.

12. Rispens T, Vennegoor A, Wolbink GJ, Polman CH, Killestein J. Natalizumab remains detectable in patients with multiple sclerosis long after treatment is stopped. Mult Scler 2012;18:899-901

13. Datta P, Baker T, Hale TW. Balancing the use of medications while maintaining breastfeeding. Clin perinatology 2019;46:367-382.

14. Greiner W, Batram M, Scholz S. Kinder- und Jugendreport 2018 Schleswig Holstein. 2018. Available at: dak.de/dak/download/report-2106236.pdf. Accessed January 13, 2020.

15. Greiner W, Batram M, Scholz S, Witte J. Kinder- und Jugendreport NordrheinWestfalen Gesundheitsversorgung von Kindern- und Jugendlichen in NordrheinWestfalen. 2019. Available at: dak.de/dak/download/download-kinder-und-jugen dreport-2019-nordrhein-westfalen-2106266.pdf. Accessed January 13, 2020.

16. Haghikia A, Langer-Gould A, Rellensmann G, et al. Natalizumab use during the third trimester of pregnancy. JAMA Neurol 2014;71:891-895.

17. Bergmann RL, Dudenhausen JW. Prädiktion und Prävention der Frühgeburt. Der Gynäkologe 2003;36:391-402.

18. Ebrahimi N, Herbstritt S, Gold R, Amezcua L, Koren G, Hellwig K. Pregnancy and fetal outcomes following natalizumab exposure in pregnancy. A prospective, controlled observational study. Mult Scler 2015;21:198-205.

19. EMA. Tysabri ${ }^{\circledR}$ (natalizumab) -EPAR Summary of Product Characteristics. Available at: ema.europa.eu/en/documents/product-information/tysabri-epar-product-information_en.pdf. Accessed February 2, 2020.

20. Matro R, Martin CF, Wolf D, Shah SA, Mahadevan U. Exposure concentrations of infants breastfed by women receiving biologic therapies for inflammatory bowel diseases and effects of breastfeeding on infections and development. Gastroenterology 2018;155:696-704.

21. Newton ER, Hale TW. Drugs in breast milk. Clin Obstet Gynecol 2015;58:868-884

22. Foley JF, Goelz S, Hoyt T, Christensen A, Metzger RR. Evaluation of natalizumab pharmacokinetics and pharmacodynamics with standard and extended interval dosing. Mult Scler Relat Disord 2019;31:65-71.

23. Giragossian C, Clark T, Piche-Nicholas N, Bowman CJ. Neonatal Fc receptor and its role in the absorption, distribution, metabolism and excretion of immunoglobulin G-based biotherapeutics. Curr Drug Metab 2013;14:764-790.

24. Oreja-Guevara C, Wray S, Buffels R, Zecevic D, Vukusic S. Pregnancy Outcomes in Patients Treated With Ocrelizumab. ECTRIMS Online Library; 2019.

25. Fritzsche J, Pilch A, Mury D, Schaefer C, Weber-Schoendorfer C. Infliximab and adalimumab use during breastfeeding. J Clin Gastroenterol 2012;46:718-719.

26. Mariette X, Forger F, Abraham B, et al. Lack of placental transfer of certolizumab pegol during pregnancy: results from CRIB, a prospective, postmarketing, pharmacokinetic study. Ann Rheum Dis 2018;77:228-233.

27. Julsgaard M, Christensen LA, Gibson PR, et al. Concentrations of adalimumab and infliximab in mothers and newborns, and effects on infection. Gastroenterology 2016; 151:110-119.

28. Deutsch-Schweizerische Versorgungsleitlinie basierend auf internationalen Empfehlungen (EACD-Consensus) zu Definition, Diagnose, Untersuchung und Behandlung bei Umschriebenen Entwicklungsstörungen motorischer Funktionen (UEMF). 2011. Available at: awmf.org/leitlinien/detail/II/022-017.html. Accessed January 13, 2020. 


\section{Neurology \\ Neuroimmunology \& Neuroinflammation}

\section{Monoclonal antibody treatment during pregnancy and/or lactation in women with MS or neuromyelitis optica spectrum disorder \\ Andrea Ines Ciplea, Annette Langer-Gould, Annick de Vries, et al. \\ Neurol Neuroimmunol Neuroinflamm 2020;7; \\ DOI 10.1212/NXI.0000000000000723}

This information is current as of April 23, 2020

\section{Updated Information \& \\ Services}

References

Citations

Subspecialty Collections

Permissions \& Licensing

Reprints including high resolution figures, can be found at:

http://nn.neurology.org/content/7/4/e723.full.html

This article cites 22 articles, 1 of which you can access for free at: http://nn.neurology.org/content/7/4/e723.full.html\#\#ref-list-1

This article has been cited by 5 HighWire-hosted articles: http://nn.neurology.org/content/7/4/e723.full.html\#\#otherarticles

This article, along with others on similar topics, appears in the following collection(s):

Cohort studies

http://nn.neurology.org//cgi/collection/cohort_studies

Multiple sclerosis

http://nn.neurology.org//cgi/collection/multiple_sclerosis

Information about reproducing this article in parts (figures,tables) or in its entirety can be found online at:

http://nn.neurology.org/misc/about.xhtml\#permissions

Information about ordering reprints can be found online:

http://nn.neurology.org/misc/addir.xhtml\#reprintsus

Neurol Neuroimmunol Neuroinflamm is an official journal of the American Academy of Neurology.

Published since April 2014, it is an open-access, online-only, continuous publication journal. Copyright

Copyright (C) 2020 The Author(s). Published by Wolters Kluwer Health, Inc. on behalf of the American

Academy of Neurology.. All rights reserved. Online ISSN: 2332-7812.

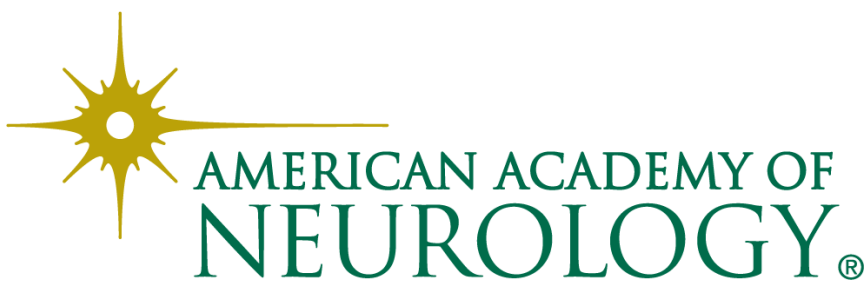

